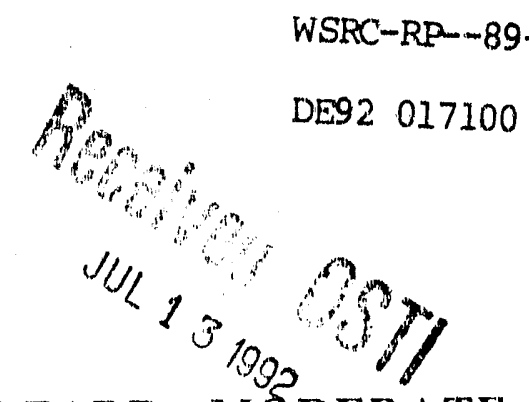

\title{
DESIGN WIND SPEEDS FOR HIGH HAZARD, MODERATE HAZARD, IMPORTANT/LOW HAZARD AND GENERAL USE FACILITIES AT THE SAVANNAH RIVER SITE (U)
}

by

\section{H. H. King}

Westinghouse Savannah River Company

Savannah River Site

Aiken, South Carolina 29808

This report was prepared in connection with work done under Contract No. DE-AC09.89SR 18035 with the U.S. Department of Energy. By acceptance of this report, the publisher and/or recipient acknowledges the U.S. Government's right to retain a nonexclusive, royalty-free license in and to any copyright covering this report, along with the right to reproduce and to authorize others to reproduce all or part of the copyrighted report.

\section{MASTER}




\section{DISCLAIMER}

This report was prepared as an account of work sponsored by an agency of the United States Government. Neither the United St'tes Government nor any agency thereof, nor any of their employees, makes any warranty, express or implied, or assumes any !syal liability or responsibility for the accuracy. completeness, or usefulness of any information, apparatus, product, or process disclosed, or represents that its use would not infringe privately owned rights. Feferense herein to any specific commercial product, process, or service by the trade name, trademark, manufacturer, or othenvise, does not necessarily constitute or imply its endorsement, recommendation, or favoring by the United States Govemment or any agency thereof. The views and opinions of authors expressed henein do not necessarily state or reflect those of the United States Government or any agency thereof. 
Nonreactor Safety Research

Savannah River Laboratory

September 11,1989

To: DISTRIBUTION

From: H. H. King, 773-41A P/gK

Nonreactor Safety Research

Design Wind Speeds for High Hazard,

Moderate Hazard, Important/Low Hazard and

General Use Facilities at the Savannah River Site (U)

NTRODLCTION:

The design wind speeds for High Hazard, Moderate Hazard, Important/Low Hazard and General Use facilities at the Savannah River Site are developed below using the procedures and site-specific hazards model required by $\boxminus O E$ Order $0430.1 \mathrm{~A}^{1}$.

SLMMARY:

The design wind speeds, calculated according to DOE Order 6430.1A, tor each type of facility at the Savannah River Site are listed below. These are less than the previously required Design Wind Speeds.

High Hazard (Maximum Resistance) Facility

Moderate Hazard (High Resistance) Facility

$185 \mathrm{mph}$

Important/Low Hazard (Intermediate) Facility

General Use (Standard) Facility

$137 \mathrm{mph}$

$83 \mathrm{mph}$

$78 \mathrm{mph}$

Keywords: Design Wind Speed, High Hazard, Moderate Hazard. Important, Low Hazard, General Use

Retention Period: Lifetime

Anuliom. Sne-fine

Authorized Derivative Classifier 


\section{DISCUSSION:}

DOE Order 6430.1A (0111-2.4.2 \& 0111-99.0.2) specifies that the procedures for determining basic wind speeds of UCRL-159102 be used in applying the site-specific hazard model studies summarized in UCRL-53526.3 Additionally, DOE Order 6430.1A s'ates that the specific guidance on relating frequency of occurrence to facility hazard levels shall be obtained from LCRL-15910.

For each building category, a basic wind speed is determined from the Wind/Tornado Hazard Curve for SRS in UCRL-53526 (Figure 1) corresponding to the hazard exceedance probability recommended for the building category by LCRL-15910. This wind speed must be fastest-mile. The wind speeds corresponding to the exceedance probability for Important/Low Hazard and General Lse facilities are from the straight wind region of the curve and are already in fastestmile. The wind speeds corresponding to the exceedance probability for High and Moderate Hazard facilities are in the tornado region of the curve. Tornado winds are gusts which must be converted to equivalent fastest mile. This is done by UCRL-15910. Table 5-2 and the equation:

$$
V_{f m}=0.958 V_{t}-11.34
$$

The UCRL-15910 procedure to obtain the design wind speed $\left(V_{d}\right)$ is to multiply the fastest-mile basic wind speed $\left(V_{f m}\right)$ by an Importance factor (I) given by UCRL-15910, Table 5-3. Importance factors are multipliers to reduce the probability of damage to meet the performance goal of the building category. Therefore, to obtain the design wind speed:

$$
\mathrm{V}_{\mathrm{d}}=\mathrm{V}_{\mathrm{fm}} \mathrm{I} \text {. }
$$

\section{HIGH AND MODERATE HAZARD FACILITIES}

UCRL-15910 recommends that SRS design for tornado type wind for II:gh and Moderate Hazard facilities. For High Hazard and Moderate Hazard facilities requiring tornado resistance, the recommended basic wind speed is based on an annual hazard exceedance probability of $2 \times 10^{-5}, 2$ 
The tornado wind recommended basic wind speed from Figure 1 corresponding to a probability of $2 \times 10^{-5}$ is $155 \mathrm{mph}$, converting to equivalent fastest mile by the equation above:

$$
\mathrm{V}_{\mathrm{fm}}=0.958 \mathrm{~V}_{\mathrm{t}}-11.34=0.958(155)-11.34=137 \mathrm{mph} .
$$

This agrees with the basic wind speeds for the Savannah River site given in UCRL-15910. Table 5-4.

For High Hazard facilities, the tornado wind Importance factor given by UCRL-15910. Table 5-3 is 1.35 . Thus. for High Hazard facilities the Design Wind Speed $\left(V_{d}\right)$ based on tornado winds is:

$$
\mathrm{V}_{\mathrm{d}}=\mathrm{V}_{\mathrm{fm}} \mathrm{I}=(137)(1.35)=185 \mathrm{mph} .
$$

Fir Moderate Hazard facilities, the tomado wind Importance factor given by LCRL-15910. Table 5.3 is 1.0. Thus, for Moderate Hazard facilities the Design Wind Speed $\left(V_{d}\right)$ based on tornado winds is:

$$
\mathrm{V}_{\mathrm{d}}=\mathrm{V}_{\mathrm{fm}} \mathrm{I}=(137)(1.0)=137 \mathrm{mph} \text {. }
$$

IAPORTANT/LOW HAZARD AND GENERAL USE FACILITIES For Important/Low Hazard and General Use facilities, the recommended basic wind speed is based on an annual hazard exceedance probability of $2 \times 10^{-2} .2$ The recommended basic wind sfeed from Figure 1 corresponding to a probability of $2 \times 10^{-2}$ is 78 moh. This also agrees with the basic wind speeds for the Savannah River Plant given in UCRL-15910, Table 5-4.

For Important/Low Hazard facilities, the Importance factor given by LCRL-15910. Table 5-3 is 1.07. Thus, for Important/Low Hazard facilities the Design Wind Speed $\left(V_{d}\right)$ is:

$$
V_{d}=V_{f m} I=(78)(1.07)=83 \mathrm{mph} .
$$

For General Use facilities, the Importance facter given by UCRL-15910, Table 5-3 is 1.0. Thus, for General Use facilities the Design Wind Speed $\left(V_{d}\right)$ is:

$$
V_{d}=V_{f m} I=(78)(1.0)=78 \mathrm{mph} .
$$




\section{REFERENCES:}

1. DOE Order 6430.1A, "General Design Criteria", United States Department of Energy (April 6, 1989).

2. UCRL-15910, "Design and Evaluation Guidelines for Department of Energy Facilities Subjected to Natural Phenomena Hazards", Lawrence Livermore National Laboratory, University of California, Livermore, California (Draft - May 1989).

3. UCRL-53526. Rev. 1. "Natural Phenomena Hazards Modeling Project:

Exireme Wind/Tornado Hazard Models for Department of Energy

Sites", Lawrence Livermce National Laboratory, University of California, Livermore, California (August 1985). 
Figure 1

(From UCRL-53526, Rev. 1)

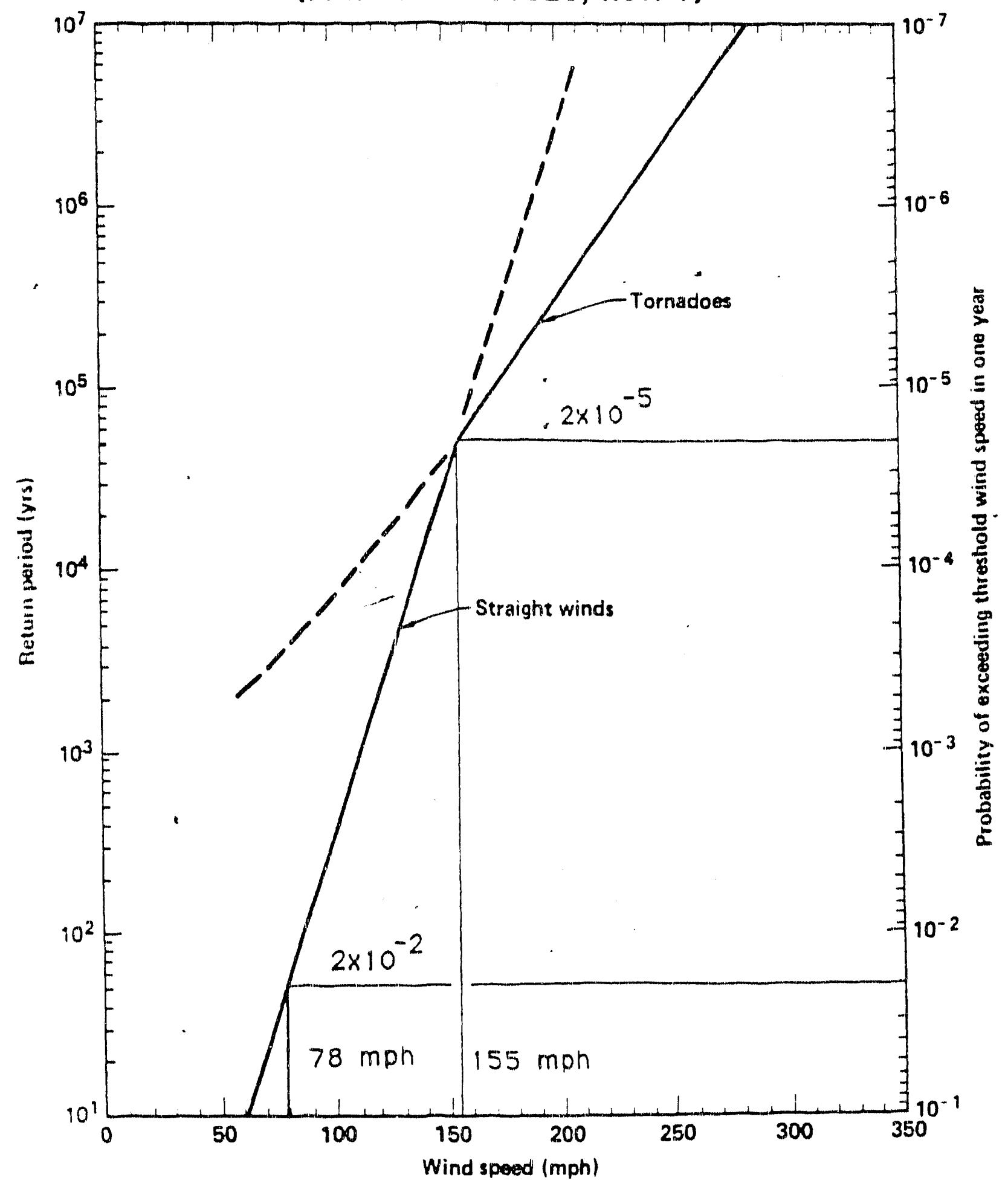

Wind Hazard at the Savannah River Plant, South Carolina ... 
DATE FILMED 8118192 
